\title{
The Theological Framework of the American Codification Debates
}

Kellen Funk

Winning submission to the Thomas I. Emerson prize for best paper on the topic of legislation Yale Law School, 2014

"Our wise law reformers in this state, a few year since, ... attempted to codify the laws so as to supersede the demand for any knowledge of the Common Law to understand them." So remarked the New York intellectual Orestes Brownson in 1871, referring to the 1848 New York Code of Procedure, drawn up by the champion of American codification, David Dudley Field. Brownson thought Field's procedure code had proven a failure. "[T] he ablest jurors in the state find [its provisions] a puzzle, or nearly inexplicable, and our best lawyers are uncertain how to bring an action under the new Code of Procedure." In fact, a large number of interpretations had developed from the code, so much so that shortly after Brownson wrote, New York replaced its original 500 sections with a 3,300-section code that consolidated the judicial glosses. ${ }^{1}$

To Brownson, the troubled history of the Field Code provided excellent proof, not just in a debate about law reform, but also in one about theology. "The Protestant, reduced to the sacred text $\ldots$, would be reduced to the condition of the lawyer who should undertake to explain the statutes of any one of our states, in total ignorance of the Common Law," Brownson argued, concluding that " $[\mathrm{t}]$ he Protestant needs, in order to interpret the sacred texts, a knowledge of revelation which can neither be obtained from the text itself without interpretation nor supplied by private judgment.” Brownson, a labor radical-turned-Transcendentalist in his youth, had by the 1870 s become one of America's leading cultural critics and an outspoken Roman Catholic apologist. A frequent social commentator, Brownson abhorred Field's procedure code when it appeared in 1848,

\footnotetext{
${ }^{1}$ Orestes Brownson, Authority in Matters of Faith, 14 CATHOLIC World 145, 155 (1871); THE CODE OF REMEDIAL Justice Passed June 2, 1876, With Full Explanatory Notes by Montgomery H. ThroOp (1876).
} 
and he was pleased in later years to see it become a byword of legislative folly, one that illustrated the Protestant's naïve faith in written texts and individual authority. ${ }^{2}$

Codification is, as Lawrence Friedman has remarked, a set piece of American legal history. Debates about the wisdom and feasibility of reducing common law rules to systematic statutes spanned the nineteenth century and involved many of the country's leading lawyers from Thomas Jefferson, Joseph Story, and Daniel Webster before the Civil War, to Francis Lieber and Christopher Columbus Langdell afterwards. The major confrontation occurred just after Brownson wrote, when David Dudley Field and James Coolidge Carter engaged in a public debate over Field's proposed Civil Code for the State of New York, a proposal that was ultimately defeated. ${ }^{3}$

Though they have long recognized the significance of the American codification controversy, lawyers and historians have struggled to understand its intellectual sources and history. Attempts to reduce the struggle over the nature and authority of "unwritten" private law to economic instrumentalism has proven unsatisfying and unable to account for the language or modes of argument American lawyers used. Equally troubling, these accounts leave the intellectual world of the codifiers under-examined. At home in the "Republic of Statutes," modern commentators claim the codifiers as their nineteenth-century forerunners, champions of a rational statutory scheme that looks familiar and sensible to us today. The mystery is why anyone would oppose modernity, and thus the defenders of the common law receive an inordinate amount of attention. ${ }^{4}$

\footnotetext{
2 Orestes Brownson, Cooper's Ways of the Hour, 5 BROWNSON’s Q. REV. 285 (July 1851); Brownson, supra note 1 , at 155. ${ }^{3}$ LAWrence M. Friedman, A History of AmErican Law 294 (3d ed. 2005).

${ }^{4}$ See Gunther A. Weiss, The Enchantment of Codification in the Common-Law World, 25 YALE J. INT'L L. 435 (2000); Andrew P. Morriss, Codification and Right Answers, 74 CHI.-Kent L. ReV. 355 (1999); The Legal Mind IN AMERICA (PERRY Miller, ED., 1962); Robert W. Millar, The Procedure of the Trial Court in Historical Perspective (1952); MAurice EugEN LANG, CODIFICATION IN THE British EMPIRE AND AMERICA (1924). Other leading works will be discussed in more detail in Part II infra. William N. EsKridge \& JOHN FEREJOHN, A RePUbliC OF STATUTES: THE NEW AMERICAN CONSTITUTION (2010).
} 
This paper will present a new direction by taking seriously what appeared so obvious to Orestes Brownson: codification debates in America were fundamentally concerned with authority, interpretation, epistemology, and the direction of history-just as Protestant and Catholic polemic were. For many during this era, legal and religious arguments relied on the same concepts, analogies, sensibilities, and frames of thought. The codifiers especially, many of whom were allied to New School Presbyterianism, adopted and expanded the language and logic of a post-Calvinistic Protestantism, one associated with the more intellectual strands of revivalism that swept America across the century. Common law defenders, in order to resist codification, accordingly had to resist New School Protestant sensibilities, and they often echoed American Catholic and Old School Protestant critiques to do so. (That the American Catholic Brownson opposed codification was more than coincidental.) A theological paradigm of individual authority, textual perspicuity, common sense rationalism, and millenarian expectation formed the intellectual framework that made codification both thinkable and desirable in America; to withstand codification, common law lawyers challenged that paradigm.

\section{The Course of the American Codification Debates}

The Revolution left American law in disarray, prompting a number of commentators to suggest either that America's break with England required a break with English common law, or that American lawyers needed at least some written guidance about which statutes and precedents were to remain in force. Virginia led the way, both in reorganizing its statutes and codifying its criminal law while leaving other fields to common law development. (Ever after, even the common law lawyers agreed that criminal law ought to remain positive law..$\left.^{5}\right)$ On this project of legislative organization even fierce political opponents like Thomas Jefferson and Joseph Story could agree. ${ }^{6}$

\footnotetext{
5 See, e.g., James CoOlidge Carter, Provinces of the Written AND the UnWritTen LaW 16 (1889).
}

${ }^{6}$ See Charles M. Cook, The American Codification Movement 33-49 (1981). 
The course of codification sharply turned in 1823, when the Irish (Protestant) émigré lawyer William Sampson addressed the New York Historical Society and called for a complete abolition of the common law in favor of a distinctively American code. Sampson's address gained national attention and significantly politicized the idea of codification. Sampson's well-known defense of labor organizers in New York inclined observers to associate his interest in codification with democratic radicalism, especially after a number of Jacksonian Democrats voiced their own support for codification in the following years. New York organized and revised its statutes in 1828, but the common law defender and former chancellor James Kent chaired the commission and ensured the Revised Statutes did not significantly abrogate the state's common law. ${ }^{7}$

Into the 1840s, codifiers offered a more moderate proposal than Sampson's. Rather than adopting a code to the total derogation of the common law, most codifiers insisted on culling together and systematizing only well-established principles from the common law reports (which, after a burst of American publishing, were growing at an unmanageable rate). Such a half measure would ease research burdens for basic matters while allowing cycles of common law development and re-codification to continue into the future. A leading proponent of this position was David Dudley Field, the Manhattan lawyer whose name became synonymous with American codification. ${ }^{8}$

In 1848, the codifiers achieved a signal victory with New York's adoption of Field's civil procedure code. Over the next several decades, the code won acceptance in nearly forty other American jurisdictions and influenced procedural reform even in England. Having convinced jurists that the "arbitrary" and "technical" field of procedure could be entrusted to the legislature, however,

\footnotetext{
7 See COOK, supra note 6, at 106-10; William Sampson, Anniversary Discourse on the Origin, Progress, Antiquities, Curiosities, and Nature of the Common Law, Delivered Before the New York Historical Society, December 6, 1823, in SAMPSON'S DISCOURSE AND Correspondence (Pishey Thompson ed., 1826); Revised StATUtes of THE STATE OF NeW York (1829).

${ }^{8}$ David Dudley Field, Reform in the Legal Profession and the Laws, in 1 SpEECHES, ARGuMENTS, AND MisCELLANEOUS PAPERS OF DAVID DudLEy FIELD 494, 513 (1855) (A. P. Sprague ed., 1884) [hereinafter SpEECHES].
} 
the codifiers had the difficult problem of then reversing their position to argue that procedure was not so exceptional after all, and that the substantive civil law should likewise be codified. ${ }^{9}$

Field thus persisted in drafting penal, political (constitutional), and civil codes for New York during the 1860s (and even an international code the following decade). The codes found some success in western states, but the effort to enact the Civil Code in New York provoked an articulate defense from the common law lawyer James Coolidge Carter, who argued against the code before the city bar association and the state legislature. Carter defeated enactment year after year-twice by securing governors' vetoes-until the state senate voted the project down. Carter's influential victory over Field in New York has since become a frequent tale in American legal history and one of its significant puzzles, since Carter's adherence to custom and common law in the 1880 s seems odd in a nation about to become so extensively governed by state codes and federal "super statutes." 10 With the rise of Legal Realism at the turn of the century, skepticism towards both the common law and the "law on the books" consigned the codification debates to the nineteenth century. Legislation multiplied exponentially while systematic organization of statutory law continued apace. Although twentieth-century statutes did not codify the common law entirely, the American Law Institute’s Restatements, Model Penal Code, and Uniform Commercial Code achieved a similar effect. Nevertheless, a few legal philosophers throughout the twentieth century persistently valorized $A$ Common Law for the Age of Statutes, to cite a recent example. The codification controversy thus has its contemporary echoes. ${ }^{11}$

\footnotetext{
${ }^{9}$ On the argument that procedure was exceptional, see Report of the Commissioners on Practice and Pleadings, in 7 DOCUMENTS OF THE AsSEMbly OF THE STATE OF NEW YORK, 70th Sess., No. 202 at 4 (1847).

10 See The Political Code of the State of NeW York (1859); The Civil Code of the State OF New York (1865); The Penal Code of the State of NeW YorK (1865). David Dudley Field, Draft OUTLINES OF AN IntERnAtional CODE (1871). See GEORGE MARTIN, CAUSES AND CONFLICTS: THE CENTENNIAL History OF THE AsSOCIATION OF THE BAR OF THE CITY OF NEW YORK, 1870-1970 at 142-57 (1970). ESKRIDGE \& FEREJOHN, supra note 4.

${ }_{11}$ On the Restatements as code substitutes, see James Gordley, European Codes and American Restatements: Some Difficulties, 81 Columbia L. Rev. 140 (1981). See Karl N. Llewellyn, The Common Law Tradition (1960); Alexander Bickel, The Morality of Consent (1975); Guido Calebresi, A Common Law for the Age OF StatuTes (1982).
} 


\section{Intellectual Histories of Codification and the Defense of the Common Law}

\section{A. Political Economy and the Codification Controversy}

Until recently, scholars seeking to explain the debates surrounding codification have followed two paths. Some attempt to trace the intellectual genealogy of either codification or "the historical school of jurisprudence" (often linked to Carter's common law thought) across the Atlantic, attempting to show a globally unified response to modernizing democratic trends. Roscoe Pound, for instance, dismissed Carter's work as a poor derivative "from Savigny through Sir Henry Maine.” Mathias Riemann and Steven Wilf similarly attribute Carter's thought—and by implication, that of other common law lawyers — to Maine and the German jurist Karl von Savigny. On the codifiers' side, the prominent intellectual historian Perry Miller asserted that Field's project owed its origins to Jeremy Bentham's campaign for codification in England, while other scholars have argued that Field's codes reflect more of the continental tradition than Bentham's prescriptions. ${ }^{12}$

In these accounts, one voice (Carter's or Field's) often speaks for a large group of lawyers, and even then, evidence on the thought of one individual tends to be shallow. Recent work by Lewis Grossman shows that Carter knew almost nothing about Savigny and was barely more familiar with Maine and the English historical school. Likewise, the civilian scholar Aniceto Masferrer demonstrates that Field's supposed reliance on either Bentham or the continental codes has been exaggerated. Field basically ignored Bentham's works, his utilitarianism, and his democratic theory, nor do Field's codes seem structurally or philosophically related to those of Europe. ${ }^{13}$

\footnotetext{
12 Roscoe Pound, Law: Its Origin, Growth, and Function, by James C. Carter, 24 POL. SCIENCE Q. 317 (1909); Mathias Reimann, The Historical School Against Codification: Savigny, Carter, and the Defeat of the New York Civil Code, 37 AM. J. COMP. L. 95 (1989); see also Steven Wilf, The Invention of Legal Primitivism, 10 Theoretical Inq. L. 485 (2009). PERRY MILLER, THE LIFE OF THE MIND IN AMERICA 243 (1965); David S. Clark, The Civil Law Influence on David Dudley Field's Code of Civil Procedure, in The ReCePtion of CONTINENTAL IdEAs In THE COMMON LAW WORLD 63 (Mathias Reimann ed., 1993). ${ }^{13}$ On the diversity within and opposed to the codification "movement," see Robert W. Gordon, The American Codification Movement, 36 VAND. L. REV. 431 (1983), Lewis A. Grossman, "From Savigny through Sir Henry Maine”: Roscoe Pound’s Flawed Portrait of James Coolidge Carter's Historical Jurisprudence (American University Washing College of Law, Working Paper No. 2009-2921). Aniceto Masferrer, The Passionate Discussion Among Common Lawyers About Postbellum American Codification: An Approach to Its Legal Argumentation, 40 ARIZ. ST. L.J. 173, 211-12 \& 233-36 (2008).
} 
On the other, more influential path, scholars examine how American political and economic concerns determined the course of the controversy. In the leading account, Morton Horwitz contends that the defense of the common law against codification was fundamentally rooted in the American laissez-faire defense of private property against redistributive legislation. Carter (again, focus rests on Carter) feared not the organization and systemization of the law, but the involvement of the legislature in this process, since it would make legislative amendment to the rules of property dangerously easy. Where Carter appealed to custom, history, or political philosophy to bolster his jurisprudence, Horwitz argues he was simply covering his opposition to redistribution. ${ }^{14}$

Unlike his supposed reliance on Savigny, Carter's sacralized view of property rights and his distrust of democratic majorities finds solid proof in his writings, but no less could be said of his opponents. Like Carter, Field was a respected corporate lawyer and Liberal Republican who opposed redistribution. He once declared that "I am free only when my person and my property are beyond the reach of any force other than the law," but he refused to recognize as law any "agrarian measure to divide property among those who have not earned it.” As economic and political “conservatives," Miller notes, the codifiers were indistinguishable from their common law opponents. Reducing the controversy to economic determinism thus fails to account for why the legal profession—which united on the question of redistribution—divided so bitterly over codification. Something more than political economy structured and informed the debates. ${ }^{15}$

\footnotetext{
14 MOrTOn J. Horwitz, The Transformation OF AMERICAN LAW, 1780-1850 at 258-59 (1977); MORTON J. HORwitZ, THE Transformation OF AMERICAN LAw: THE Crisis OF LEGAL ORTHODOXY, 1870-1960 at 117-21 (1992); Horwitz's thesis has been expanded by COOK, supra note 6; and Gordon, supra note 13 (arguing that lawyers permitted procedural codification only to deflect substantive codification and "real reform" proposals that would have altered the social and economic order).

15 See, e.g., James CoOlidge Carter, The Proposed Codification of Our Common Law: A Paper Prepared at

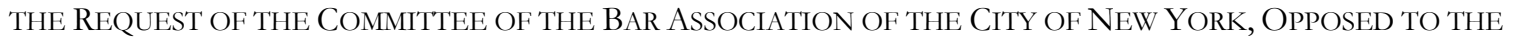
MEASURE 37 (1884); CARTER, supra note 5, at 36. David Dudley Field, Address Before the Adelphic Union Society of Williams College, July 5, 1875, in 2 SPEECHES, supra note 8, at 299, 315 (1875); David Dudley Field, Corruption in Politics, in 2 SPEECHES supra, 128, 136 (1877). MILLER, supra note 12, at 259.
} 


\section{B. Cultural History and the Defense of the Common Law}

The most recent scholarship on the defense of the common law looks to the common law lawyers' cultural context in order to understand their jurisprudence. Lewis Grossman argues that Carter's "precarious synthesis of apparently inconsistent elements," gains clarity and coherence the more we understand the patrician "Mugwump" Republican society of which Carter was a part, one that both urged legislative reform yet limited legislation's reach by local custom. ${ }^{16}$ Kunal Parker examines the thought of many common law lawyers across the nineteenth century to demonstrate how prevailing theories of history motivated a principled defense of the common law before the rise of "legal modernism." While historicists like Oliver Wendell Holmes Jr. believed history served only antifoundational purposes, melting all claims of law into temporal politics, common law lawyers, following various trends in Romantic or Darwinian literature, saw history imbued with a logic that naturally but necessarily restrained democratic politics (though particular logics of history might vary from writer to writer and decade to decade). ${ }^{17}$

By taking seriously the language and modes of thought the common law lawyers actually used, these studies are on steadier evidential ground than the transatlantic genealogies. Paying attention to the particular political and cultural concerns that informed their thought further helps us to see why lawyers like Carter were so influential and esteemed by the American public. ${ }^{18} \mathrm{~A}$ problem with these accounts, however (besides excluding religion as a major part of "culture"19), is that they

\footnotetext{
${ }^{16}$ Lewis A. Grossman, James Coolidge Carter and Mugwump Jurisprudence, 20 L. \& HIST. REV. 577 (2002).

${ }^{17}$ Lewis A. Grossman, Langdell Upside-Down: James Coolidge Carter and the Anticlassical Jurisprudence of Anticodification, 19 YALE J. OF L. \& Humanities 149 (2007); KunAl M. PARKer, COMmOn LAw, History, AND Democracy IN AMERICA, 1790-1900: LEGAL THOUGHT BEFORE MODERNISM (2011).

18 On Carter's public renown, see Grossman, supra note 13, at 1-4.

${ }^{19}$ Parker rightly notes that "the presence of religion in nineteenth-century American thought, if offered up as a definitive and all-encompassing explanation ... risks becoming monolithic and reductionist.” But in order to avoid the risk of reductionism, Parker says nothing further about the influence of religion on nineteenth-century American thought at all. PARKER, supra note 17, at 12. Grossman argues that "the Mugwumps' outlook became increasingly secular during their maturity in the age of Darwin," and only "their ethical code survived the erosion of the religion foundation on which [their outlook] originally rested." Grossman demonstrates that "[i]t is impossible to understand Mugwump jurisprudence without grasping the importance of this ethical system," but as I will argue below, Carter's jurisprudence contained more
} 
tell only one side of the story. Like Horwitz, each adopts the assumption that the defense of the common law was such a peculiar or retrograde position that it requires careful explanation, while the position of the codifiers was straightforward, sensibly progressive, and thus able to be ignored while the explication of the common law defense proceeds. ${ }^{20}$

The problem with this exclusive focus is that it uncritically adopts the codifiers as forerunners of modern lawyers and bureaucrats comfortable with wide-ranging statutory law. Today, the abundance of state codes systematizing and reforming rules that formerly arose from the common law seems to prove that the codifiers were right - there really was nothing to fear about their program. The codifiers, however, were products of their time-not of ours. Their modes of thought and assumptions came not from the twentieth-century administrative apparatus, but from nineteenth-century governance, not least of all from a revivalistic Protestant establishment. In order to understand the ferocity and the importance of the codification controversy, historians must pay closer attention to, among other facets, the religious idiom and logic of the codifiers.

Doing so will not only show the disruptions between nineteenth-century lawyers and modern theorists of statutory law, it will also help clarify what is normally considered the big puzzle: why the common law lawyers defended their system the way they did. Carter, after all, insisted that he thought little about the nature of jurisprudence until Field's civil code roused him from his dogmatic slumber. According to him, all his jurisprudential writing was a direct response to Field's philosophy. ${ }^{21}$ Attempting to tell the history of common law jurisprudence without accounting for the thought of the codifiers is thus — to pick a contemporaneous example—like writing a history of

\footnotetext{
than just the "moralism" remaining from the "Second Great Awakening" to which Grossman directs us. Grossman, supra note 16, at 594.

20 See, e.g., HORWITZ, CRISIS, supra note 14, at 117-21.

21 See Grossman, supra note 13, at 2-4.
} 
the American Whigs while ignoring Andrew Jackson and the Democrats: We are told the story of a rebuttal without ever hearing the opening argument.

\section{Christian Nationalism and the Christian Identity of the Common Law}

A full account of the influence of American thought and culture on the nineteenth-century codifiers would likely require attention to the emergence of democratic politics of the Second and Third Party Systems, the transition of labor practices to industrialization and commercial finance, the religious upheavals of the Second Great Awakening and "businessmen's revivals," andinvolved in all of these-the increasingly pervasive language of science, whether "political science," "scientific management" or the "science of revival." Of these themes, the effect of American religion on American legal thought is perhaps the most neglected. ${ }^{22}$

Recently scholars of American law and religion in the nineteenth century have sought to demonstrate how American Protestants enjoyed a de facto national religious establishment. ${ }^{23}$ According to Steven Green, the Protestant establishment's power became most visible in the assertions by jurists that America was a Christian nation with a Christian common law. Chancellor Kent, Lemuel Shaw, Joseph Story, and Daniel Webster all made such pronouncements in the antebellum era. After the Civil War, lawyers continued to argue for the Protestant identity of the common law in the "Bible Wars," as Catholics sought to escape the coerced reading of the King James Bible in the public schools, and in the anti-polygamy campaign that withheld statehood from

\footnotetext{
22 Useful works in these fields that give particular attention to New York, where codification efforts were more extensively debated, include CHARLES W. MCCURDY, THE ANTI-RENT ERA IN NEW YORK LAW AND POLITICS: 18391865 (2000); SEAN WILENTZ, CHANTS DEMOCRATIC: NEW YORK CITY AND THE RISE OF THE AMERICAN WORKING Class, 1788-1850 (2D. ed., 2004); SvEn BECKERT, MONIED METROPOLIS: NEW YORK CITY AND THE CONSOLIDATION

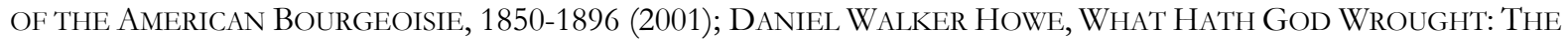
Transformation of AMERICA, 1815-1848 (2009); NATHAN O. HATCH, THE DEMOCRATIZATION OF AMERICAN CHRISTIANITY (1991). On the pervasive language of science, see HowE, supra at 463-69. Legal historians are only now beginning to give serious consideration to the influence of religious thought on the development of legal doctrine in America. See especially SusAnNa L. BlumentHal, LAW AND THE MODERN Mind: ConsCiOUSNESS AND RESPONSIBILITY IN AMERICAN LEGAL CUlTure (2014).

${ }^{23}$ For a useful review of the current literature, see Sarah Barringer Gordon, Where the Action Is-Law, Religion, and the Scholarly Divide, 18 RELIGION \& AM. CULTURE 249 (2008).
} 
Utah until 1896. In 1892, Justice David Brewer (Field's nephew), wrote for a unanimous Supreme Court that "a volume of unofficial declarations" as well as a "mass of organic utterances" in America's public law proved "that this is a Christian nation." 24

On the other hand, a majority of American lawyers seem to have agreed with Francis Wharton, whose famous criminal law treatise explained that "the ethical rules of Christianity" had influenced the common law insofar as Americans had "made indictable breaches of domestic duty which were not criminally punishable by the old Roman law," and witnesses customarily took their oath upon a Bible. "[B]eyond this," Wharton declared, "we have not gone," and the idea of a Christian common law was nonsense. "Christianity, as a religion, is an affair of the individual alone," one of Wharton's reviewers agreed. Its own teaching “implies as within its proper import the separation of dogmatic Christianity and the law." 25

Those who dismissed the maxim that Christianity formed part of the common law exhibited what Perry Miller describes as a puzzling “tension between law and Christianity in America.” Miller implies that law replaced Christianity as an intellectual system for many Americans, and Wharton's account supports the idea. Whereas Christianity for figures like Joseph Story supplied a system that could unite Americans divided by politics and geography, law itself could fulfill this role for his opponents. Religion, even when shared, was solely an individual affair, while law created real social bonds. Christianity could contribute a few ethical rules, but it offered them to a preexisting legal

\footnotetext{
24 Steven Green, The Second Disestablishment (2010). See People v. Ruggles, 8 Johns 545 (Sup. Ct. N.Y. 1811) (Kent); Commonwealth v. Kneeland, 37 MASs. (20 PICK.) 206 (Sup. Ct. Mass. 1838) (Shaw); Vidal v. Girard's Executors, 43 U.S. 127 (1844) (Webster); Church of the Holy Trinity v. United States, 143 U.S. 457, 471 (1892) (Brewer). R. KENT

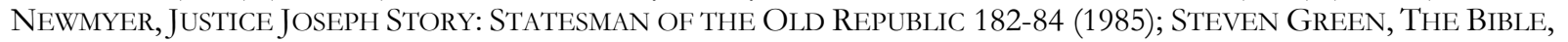
THE SCHOOL, AND THE CONSTITUTION (2012); SARAH BARRINGER GORDON, THE MORMON QUESTION 65-75 (2002). ${ }_{25}$ Miller, supra note 12, at 197; A. H. Wintersteen, Christianity and the Common Law, 38 AM. L. REG. 273, 284-85 (1890) (quoting FranCIS WHARTON, PHILOSOPHY OF CRIMINAL LAW 28-29 (1880)).
} 
structure that maintained its autonomy. In competition with revivalist Christianity, Miller concludes, jurists offered law as an intellectually coherent source of national identity. ${ }^{26}$

Many who debated the Christian nature of America's common law also joined in the codification controversy, but since most sought to secure the autonomy of law, they did not always explicitly or directly appeal to religious authority to support their jurisprudence. To leave the matter there, however, would uncritically accept Wharton's view, that where jurisprudence did not unequivocally cite its theology, Christianity had no influence. Instead, scholars of law and religion since the 1980s have shown how patterns of thought and narrative normally considered "religious" have indeed structured legal jurisprudence. Such scholarship raises the suspicion that what Wharton, a devout Protestant, may have missed (and could afford to miss, given the Protestant establishment) was how deeply American Protestant thought shaped the jurisprudential system he described. ${ }^{27}$

Miller's choice to unite American revivalism with the codification controversy in a single work of intellectual history was perceptive. The relationship, however, was less one of substitution than analogy. Whether or not lawyers sought to replace religion with law, they drew their arguments and assumptions from the theological controversy of Protestant revivalism that preceded the legal debates in America. At times, they did so explicitly. "[T] heology admits of a closer comparison with the [law], than any other science does," wrote the common law lawyer John Pickering in 1834, proceeding to deny the virtue of legislation given the inability of Christians to agree on interpretations of scripture. Later in the century, R. Floyd Clarke agreed on different grounds: "The Religious Code [the Bible] of earlier centuries is as truly the work of man, as any Code of laws ever made by man; and the analogy between them is, therefore, perfect." As the Bible had "codified"

\footnotetext{
26 See MILLER, supra note 12, at 114 (replacement of clergy with lawyers as major professional class), 133-34 (quest for universal law as the replacement of religious millennial fervor), 190 (lawyers offered a "religion [that] was social"), 197 ("tension between law and Christianity"), 258-64 (legal nationalism and legal cosmopolitanism). 27 See especially Winnifred Fallers Sullivan, THE Impossibility OF Religious Freedom (2007); Harold J. Berman, LAW And Revolution 558 (1983); Robert M. Cover, Nomos and Narrative, 97 Harv. L. Rev. 4 (1983).
} 
primitive science, so would legal codification improvidently freeze the law at an imperfect state of understanding. ${ }^{28}$ The high church Pickering, the religious modernist Clarke, the Catholic Brownson—each made his rebuttal by analogy to theology. Against what were they arguing?

\section{The Theological Structure to the American Codification Debates}

The codification debates provoked wide-ranging arguments and diverse approaches from legal commentators. No two codifiers_-or common law lawyers_-agreed on all points, but debate centered most frequently and most heatedly on four themes: the locus of legal authority, the nature and interpretation of legal texts, the means of knowledge, and the direction of history. Before these issues sharpened in the 1820s, many had already encountered them in America's tumultuous religious revivals, a major wave of which began in 1801. The revivalistic "New School” Protestant approach to these problems significantly influenced codification movements through the rest of the century, thus prompting opponents of codification frequently to contend with the deepest assumptions of New School Protestant thought.

\section{A. The Second Great Awakening \& New School Protestantism}

What some historians call the "Second Great Awakening" began in 1801 in two locations of widely varying temperament: Timothy Dwight's Yale College and an enormous camp meeting at Cane Ridge, Kentucky. After both places reported mass conversions, "revivals of religion" became of ceaseless interest to American Protestants of all classes until at least the Civil War. Nationally, church membership rose from below ten percent after the Revolution to more than thirty-five percent by mid-century. Since full membership remained an arduous process in most denominations, such numbers underreport Christian enthusiasm. As the historian Mark Noll puts it,

\footnotetext{
28 John Pickering, A Lecture on the Alleged Uncertainty of the Law, 12 AM. JURIST 285, 293-94 (1834); R. FLOYD CLARKE,
} THE SCIENCE OF LAWMAKING 367 (1898). 
"the people of the United States were each hearing several more times the number of Methodist sermons each year than they received pieces of mail.” Newspapers regularly reported on revivals and effective preachers like Charles Finney and Lyman Beecher became some of America's leading celebrities. $^{29}$

As had been the case with America's "First Great Awakening” (ca. 1740s), the mass conversions, emotional enthusiasm, and sustained interest in spirituality strained traditional theology for explanation. The Calvinism of the Puritans had emphasized the utter inability of humans to change their state before God. Only the unconditional action of divine grace turned an individual towards repentance, and to arrive at the knowledge of one's own conversion to grace required a long, uncertain, and gradual journey. These tenets no longer seemed to hold, however, as more and more Americans responded immediately to the preacher's call for repentance and seemed sure that God's grace had been extended to them. How to secure the gains of revival within orthodox theology became a central problem for America's Protestant theologians in the Early Republic. ${ }^{30}$ The reconfiguration of Calvinist orthodoxy took various shapes based on region, class, denomination, and place of education for the theologians involved, but the revivalists' views tended to converge on the issues of authority, interpretation, epistemology, and history. For convenience' sake, we may call this overall position "New School Protestantism," after its most influential proponents, the New School Presbyterians. ${ }^{31}$

\footnotetext{
${ }^{29}$ See Sydney Ahlstrom, A Religious History of the American PeOple 403-90 (1972); Roger FinKe \&

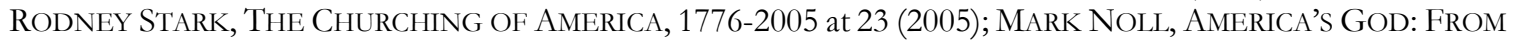
JONATHAN EDWARDS TO ABRAHAM LINCOLN 201-02 (2002). For a particularly perceptive account of theology in the western revivals, see PAUl K. CONKLIN, CANE RIDGE: AMERICA'S PENTECOST (1990).

30 On Puritanical Calvinism, see Noll, supra note 29, at 19-50; David D. Hall, A Reforming PEOPLE: Puritanism AND the Transformation of Public Life in NeW ENGLAND (2011). See Noll, supra, at 293-329; AhLSTROM, supra note 29, at 415-28.

31 Prominent New School Presbyterians included Charles Finney, Lyman Beecher, and Albert Barnes. Prolific publishers and respected educators, they influenced the course of American theology to an impressive extent given their small numbers. There is of course some strain in viewing all American revivalists under a common theological label. While marked differences separated New School Presbyterians from the New Light theologians following Jonathan Edwards (Samuel Hopkins, Joseph Bellamy, and Jonathan Edwards Jr.) and the New Haven Theology under Nathaniel William Taylor at Yale, all pursued similar lines of reasoning about the nature of man and the interpretation of scripture.
} 
Whether or not New Schoolers tried to remain under the Calvinist banner, they all insisted that individuals had the responsibility — and thus the ability — immediately to obey the gospel call. Spiritual authority thus devolved onto ordinary individuals, even within hierarchical denominations. The historian Nathan Hatch argues that American Protestantism became significantly decentralized in the Early Republic as Christian populists rejected traditional claims to authority based on ministerial education, denominational licensing, or any other mechanism that sharply distinguished the spiritual qualifications of clergy from the laity. Salvation was no longer to be mediated through a long course of catechetical instruction by trained elites; in some denominations, recently converted farmers had all the qualifications they needed to become gospel preachers. Although Presbyterians remained influential publishers, by far the largest gains in adherents went to those who granted more authority to ordinary congregants, such as the Methodists, Baptists, and Disciples of Christ. ${ }^{32}$

The authority of ordinary individuals to apprehend and accept the doctrines of salvation gave unprecedented importance to the Reformation idea of biblical perspicuity. Against Catholic teaching that only the magisterium of the church pronounced the interpretation of scripture, Protestants had for centuries insisted that scripture was sufficiently clear about important doctrines (those pertaining to salvation especially), that any believer guided by the Holy Spirit could discern them. Against Catholic tradition, Protestants taught that the Bible alone (sola scriptura) "was the only reliable source of religious authority." Noll shows how Americans pressed these ideas further,

\footnotetext{
Methodists, strong critics of Calvinism since their inception, had fewer theological readjustments to make, although they too devoted increasing attention to questions of scriptural interpretation, and they adopted peculiarly American blends of popular authority and common sense rationalism. Religious mavericks such as Alexander Campbell (founder of the Disciples of Christ) would not have said they followed any "school" at all, but their disagreements with fellow Protestants concerned only the consequences of their shared assumptions regarding the ability and authority of individuals to understand scripture and bring about the purposes of God in history. See generally E. BROOKS HOLIFIELD, Theology In America: Christian Thought From the AgE of THE Puritans to the Civil War (2003); NOLL, supra note 29; AHLSTROM, supra note 29. "New School Protestantism" is more historically specific than the problematic term "evangelical," and I use it to draw attention to the often overlooked fact that the religious revivals did indeed produce a formal, disciplined theology, whatever emotional or supposedly "antinomian" impulses raged within the radical elements of the revivals. Cf. CHARLES SELLERS, THE MARKET REVOLUTION (1994).

${ }^{32} \mathrm{HATCH}$, supra note 22, at 5 . On the contrast between catechetical conversion and more immediate evangelical forms, see especially the discussion in Albert J. RABOtEAU, SLAVE RELIGION 97-120 (2d. ed., 2004).
} 
insisting "that personally appropriated understanding of Scripture was the only reliable means of interpretation." Many American churches accordingly professed "no creed but the Bible," while others speculated that perspicuity extended not just to the spirit-filled, but to any ordinary reader. ${ }^{33}$

Noll contends that popular authority became more defensible after the American embrace of Scottish common sense rationalism. A response to Enlightenment skepticism (religiously motivated for some), common sense realism affirmed that the ordinary faculties of human perception and reasoning could indeed arrive at objective truth. Significantly deviating from a Calvinist insistence on man's fallen and depraved nature, common sense (particularly Francis Hutcheson's variety) won over Americans by offering "a scientific, universal, and optimistic ethical theory that did not require the sanction of tradition." The philosophy, in essence, offered to render all of God's works perspicacious: Humans could not only read and understand the scriptures for themselves, they could also scientifically read "natural revelation," examining their own minds and the natural environment to arrive at universal truth without guidance from mysterious traditions or archaic superstitions. ${ }^{34}$

The New School retained one significant aspect of American Calvinism in its sense of where history was going: The Reformation would ultimately culminate in the Millennium, a time of unprecedented peace, prosperity, and universal Christianity, at the end of which Jesus Christ would return to inaugurate his unending kingdom. New Schoolers insisted that revivals were critical to this process. The Reformation had helped to clear the ground of superstition and the despotism of clerics; mass conversions and heightened spirituality would lead the world forward to the climax of

\footnotetext{
${ }^{33}$ Nold, supra note 29, at 231, 367-84; HolifiELD, supra note 31, at 319-40, 418-21. Keith D. Stanglin, The Rise and Fall of Biblical Perspicuity: Remonstrants and the Transition toward Modern Exegesis, 83 CHURCH HISTORY 38 (2014).

${ }^{34}$ NoLL, supra note 29, at 109-110. Recently, Susanna Blumenthal has studied how America's transition from Calvinism to common sense profoundly affected testamentary law; see BLUMENTHAL, supra note 22.
} 
history. The dramatic success of the revivals and the growing power of benevolent organizations in America led some New Schoolers to suspect that America had a special role in millennial history. ${ }^{35}$

New School Protestantism encountered opposition on many grounds. Unitarian rationalists sneered at untrained ministers and the lengths to which they stretched the idea of perspicuity. Old School Presbyterians at Princeton insisted that revivalism conform itself to Calvinism and not the other way around. Roman Catholic apologists contended that common sense was not as common as Protestants hoped, nor was scripture so easy to interpret. The rapidly growing number of Protestant schisms, Catholics argued, stemmed naturally from the encouragement of individuals to pursue their own reading of scripture, which inevitably produced intractable divisions. ${ }^{36}$

Alongside these recriminations of "sectarianism" and "superstition," the legal codification debate came to maturity. In some cases, legal or religious thinkers may have drawn ideas independently from the same source, such as Scottish philosophy. Nevertheless, in the years preceding the codification controversy American Protestants had shown how to apply common sense philosophy and a widely accepted logic of history to the interpretation of texts and the articulation of popular authority for moral norms. Many of the proponents of codification were in fact New School Protestants, and after the Second Great Awakening their legal philosophy showed a close affinity for New School theology, more so even than for democratic political theory or Enlightenment rationalism as these were developing in Europe.

\section{B. The Locus of Legal Authority}

Lawrence Friedman writes that the codifiers hoped to make litigation "so simple and rational that the average citizen could do it on her own." Such a claim points towards the view of authority

\footnotetext{
35 Howe, supra note 22, at 285-319; JAMES MOORHEAD, WORLD WiTHOUt END: MAINSTREAM AMERICAN PROTESTANT Visions OF THE LAST THINGS (1999); HOLIFIELD, supra note 31, at 319-40.

36 See generally, HOLIFIELD, supra note 31. See especially NOLL, supra note 29, at 386-438; HATCH, supra note 22, at 49-66.
} 
the codifiers held, although it goes well beyond the position most were comfortable taking. As in New School Protestantism, the codifiers wrestled with an ambiguity as to whether the egalitarian impulses in their movement properly applied to all people, all insiders (i.e., Christians/lawyers), or only educated insiders (academic philosophers). While some notable codifiers like the Delaware legislator Jesse Higgins hoped that codes would rid America of the legal profession entirely, most agreed that " $[\mathrm{t}]$ hose who indulge the pleasing hope of making the law so simple, that every man will be his own lawyer, may rest assured that such hopes will never be realized this side of utopia," as the

\section{U.S. Monthly Law Magazine put it. ${ }^{37}$}

What the codifiers agreed upon, however, was that the law did not need to be mediated through judicial authority. "In monarchical or aristocratic governments, it would not be so much to be wondered at that a class should arrogate to itself the knowledge and interpretation of laws; but that this should happen in a republic, where all the citizens both legislate and obey, is ... incredible," Field wrote. Since "all the citizens both legislate and obey," codifiers treated the claim that judges had special authority to declare and apply the law as similar to the claim that priests had special powers to absolve sin—an explicit comparison the codifiers often made. American judges, declared Higgins, were like "the Romish priesthood when that imperious hierarchy was most ambitious and intolerant; ... they were learned, and laymen ignorant." Likewise, the New Yorker Henry Dwight Sedgwick and the South Carolinian Thomas Smith Grimké mocked the "superstition" and "superstitious venerations" of the common law, using language typical of anti-Catholic polemic. ${ }^{38}$

\footnotetext{
${ }^{37}$ FrIEDMAN, supra note 3, at 297. On Higgins's views, see [JESSE HigGINS], SAMPSON AGAINST THE PHILISTINES, OR The Reformation of Lawsuits (1805); G. S. Rowe, Jesse Higgins and the Failure of Legal Reform in Delaware, 1800-1810, 3 J. OF THE EARLY REPUBLIC 17 (1983). Nature and Method of Legal Studies, 3 U.S. MontHLy L. MAG. 379, 380 (1851). Field in particular opposed the everyman-his-own-lawyer ideal. "Justice is attainable only through lawyers," he told law students. "Only a few men, set apart for that particular calling, and devoting to it the best part of their lives," could learn and apply the law. Field, supra note 8, at 499. On the parallel Protestant ambiguity, see HATCH, supra note 22, at 179-83. ${ }^{38}$ Field, supra note 8, at 510. [HIGGINS], supra note 37, at 16. THOMAS SMITH GRIMKÉ, AN ORATION ON THE PRACTICABILITY AND EXPEDIENCY OF REDUCING THE WHOLE BODY OF THE LAW TO THE SiMPLICITY AND ORDER OF A CODE 6, 21 (1827). [Henry Dwight Sedgwick], Review of An Anniversary Discourse by William Sampson, 19 NO. AM. REV. 411, 421 (1824). Compare with NOLL, supra note 29, at 81, 91, 284; PARKER, supra note 17, at 121-22.
} 
In their distrust of judicial authority, American codifiers generally opposed the system of equity (chancery). English codifiers such as Bentham sought to reform equitable procedure but otherwise appreciated the less formal and more discretionary remedies granted in chancery. Americans followed an opposite impulse: Codifiers like Field were content to keep certain equitable (written, jury-less) procedures while campaigning to abolish equity as a system of discretionary justice (as Field did in New York). The common complaint was an old one, that justice in equity was "the measure of the Chancellor's foot": variable, depending upon the conscience of the chancellor, constrained by no statute or text promulgated by popular authority—that is, it was "priestcraft." 39

Early in the republic, Story and Kent launched American case reporting to show that both equity and common law judges used public, principled reasoning to reach their decisions. The accretion of precedent irritated the codifiers, who complained not only about the growing bulk of case reports and the difficulty of digesting them, but also about precedential reasoning itself. Precedent appealed to tradition and validated the authority of the judge as the interpreter of tradition. Codifiers like Sedgwick condemned "the veneration and obedience paid to authority and precedent" in both law and religion, and they especially objected to the "air of mystery" in the judicial process. Because precedents had become so numerous and could potentially lead in many directions, judges continued to exercise significant discretion. Despite the increasing publication of judicial opinions, codifiers suspected that judges continued to exercise their authority using non-public, mysterious reasoning, again making explicit comparisons to the Catholic priesthood. ${ }^{40}$

\footnotetext{
${ }^{39}$ DAvid Dudley Field, RE-Organization of the Judiciary 4-5 (1846); see N.Y. CONST. of 1846, art. VI, §3, art. XIV, IS 5-8. See also, MILLER, supra note 12, at 171-80. 3 BLACK. COMM. 432. On Bentham's views, see his Equity Dispatch Court Bill and accompanying commentary in 3 WORKS OF JEREMY BENTHAM 305-20 (John Bowring, ed., 1843). On the use of "priestcraft," see PARKER, supra note 17, at 121-22.

40 On the growth of American law reporting, see JOHN H. LANGBEIN ET AL., HISTORY OF THE COMMON LAW 824-33 (2009). [Sedgwick], supra note 38, at 418. See, e.g., [HIGGINS], supra note 37, at 16 (charging the "Romish priesthood" with crafting "every thing which has changed simple justice into a professional mystery").
} 
Beyond criticizing judges, some codifiers said that all lawyers who defended the common law system presumptuously set themselves above popular authority. "He seems to care nothing, [for] the opinions of other men," Field said of Carter. "He knows what is good for them better than they know themselves." To explain why common law lawyers persisted in their arrogance, Sedgwick compared them to Catholics. Noting that several otherwise brilliant men adhered to Catholicism, a religion "equally at variance with right reason and divine revelation," he surmised that they did so only because they "had been brought up to be catholics. . . . Had these men been born in a protestant country," they would have been "champions of a purer faith." So too the common law lawyer:

The faith of the lawyer is much akin to that of the [Catholic] theologian. He is brought up to think with the highest reverence of the wisdom of our ancestors, and especially the wisest of them, the ancient sages of the law. These are to him the holy fathers, whose creed he thinks it almost impious to doubt. . . To his mind, law and justice are identified with the particular forms, modes, and principles in which he has been accustomed to see them dispensed, and any interference with these he considers as endangering the existence of all law and justice, in the same way in which many pious Christians sincerely believe the particular rites and dogmas of their own sect to be the very body and soul of religion, and that whatever affects the one must endanger the other.

In both cases, Sedgwick saw the same problem: certain Americans had simply grown up too accustomed to the authority of tradition and hierarchy. ${ }^{41}$

On the question of authority, common law defenders drew fewer analogies explicitly from religion than did the codifiers, but they echoed Catholic and high church criticisms of New School Protestantism by arguing that the codifiers had a naïve view of authority. Since all authority was naturally and necessarily mediated, the codifiers did not amplify popular authority, they really only substituted one privileged class with another. Codifiers like the New York lawyer Robert Fowler had asserted that "where the people make the laws, the people alone codify them." The common law

\footnotetext{
${ }^{41}$ David Dudley Field, A Short Response to a Long Discourse 8 (1884); [Henry DWight SedGWick], The ENGLISH PRACTICE 6 (1822).
} 
lawyers retorted that "the people" never drafted codes. Even their elected representatives usually assigned the task to three- or two-member commissions. "The complaint" about judge-made traditions, argued Carter, "really amounts to this, that judges make the law instead of commissioners." Ordinary people would never enjoy unmediated understanding of the law or access to justice-the codifiers' resolve to maintain the privilege of the legal profession admitted as much. Better, then, to favor the judicial community, and for the common law lawyers, community was a key term. Like Carter, they did not express a preference for "the judge" or "the judiciary" in contrast to legislators; instead they opposed "the body of judges" to an individual commissioner such as Field: An interpretive community dedicated to that enterprise versus the individualized reading of a single lawyer. ${ }^{42}$

Scholars usually emphasize Carter's belief in custom as a source of law, but they miss the role Carter assigned to communal reason to discern the unwritten "social standard of justice." Judges "know and it and feel it because they are a part of the community. And moreover it is placed before them in a blaze of light by the animated debates of thousands of other professional men belonging to the same community, whose vocation is to study and apply it." But Field, an individual interpreter of the law, "demands by his Civil Code that his statement of the law, in every instance, right or wrong, be made the law.” Attacking the American view of codification, common law lawyers implicitly agreed with critics of New School Protestantism that individual authority and "private judgment" were inferior to the authority of a hierarchically organized interpretive community. ${ }^{43}$

\footnotetext{
42 Robert Ludlow Fowler, Codification in the State OF New York 13 (2d. ed., 1884). CARTER, supra note 15, at 42. See also William B. HORNBLOWER, Is CODIFICATION OF THE LAW EXPEDIENT? 18 (1888) (“commissioner-made law or politician-made law."); CARTER, supra at 23 ("He asks that the Legislature accept [a code] upon the authority of the two names subscribed to it."). Common law lawyers did not oppose all legislation. Carter favored codification of the criminal law, constitutional law, and new laws regulating commercial instruments. In Carter's view, however, legislation of this sort was concerned only with policy, whose aims could be democratically selected. Justice, especially in civil transactions, could not be defined or dictated through legislation-only an act of judgment could do that. CARTER, supra note 5, at 1618, 52-55. Compare with JOHn T. MCGREEvy, CATHOLICISM AND AMERICAN FrEedom: A HiSTORY 26, 36, 52 (2003); HOLIFIELD, supra note 31, at 424-46 ("Catholic theologians stood for communal reason rather than private rationality.") 43 See, e.g., HORWITZ, supra note 14, at 117-21. CARTER, supra note 5, at 42; CARTER, supra note 15, at 22. By 1850, the structure of court system to provide for appeal in most cases was seen as a common law advantage; see, e.g. ALBERT MATHEWs, Thoughts on CODifiCATION OF THE COMMON LAW 24 (4th ed. 1887) (“All of this class of arguments against what is styled judge-made-law, or case-law, as distinguished from codification, are apt to leave out of view the
} 
On this reasoning, the common law lawyers defended equity as a substantive system. Codifiers disparaged equity by linking judicial discretion to priestly discretion and equity courts to ecclesiastical courts in Europe. Common law lawyers, however, found this association praiseworthy. Carter-like many American jurists_-regarded European institutions as arbitrary and despotic, but he thought ecclesiastical courts were an exception, since "human custom may be, and often is, recognized and sanctioned in [their] administration.” Despite a legislative canon law, most civil matters, Carter supposed, were decided by local ecclesiastics familiar with the customs of the community and of the church. In his Introduction to American Law, Timothy Walker went further: "If a statute could be imagined to have a mind, . . . it would be a perfect chancellor, as well as judge.” A skilled chancellor was a statute come to life, the living embodiment of text and tradition. To object that a chancellor ruled like a priest according to "discretion" or "conscience" missed the point: Judges were trained in a specialized interpretive community and applied its traditions to the community at large. As bare texts, statutes offered nothing comparable. ${ }^{44}$

Like Catholic polemicists, common law lawyers pointed to the internal divisions of the codification movement as proof that the codifiers' promotion of popular authority undermined their own movement. Carter wrote that "the irreconcilable difference of opinion among the advocates of codification concerning the most important questions," made the meaning and virtue of "codification" differ according to the beholder. The Philadelphia lawyer Joseph Hopkinson warned that a code might contain "the arbitrary dictates of a single man, or any body of men, who

corrective power of appeal."); and CARTER, supra note 15, at 42. Compare with MCGREEVY, supra note 42, at 52-54; HOLIFIELD, supra note 31 , at 426.

44 Miller, supra note 12, at 176-77. JAMEs COOLIDGE CARTER, LAW, ITS ORIGINS, GROWTH, AND FUNCTION 101-04 (1907). TIMOTHY WALKER, INTRODUCTION TO AMERICAN LAW 56 (6th ed., 1874). 
promulgate their own individual sense of right and justice." Without a designated interpretive authority and salutary checks from an appellate hierarchy, what remained besides private judgment? ${ }^{25}$

The codifiers answered with their belief that they could find non-controversial, universal legal principles within the texts used by the legal community. This belief plunged them deeper into debate over the nature and interpretation of written texts.

\section{The Nature and Interpretation of Texts}

After all Americans had accomplished to revolutionize politics and religion, remarked William Sampson in his widely reprinted address, they retained "one pagan idol to which they daily offered up much smoky incense": the common law, sitting "upon its antique altar, for no use or purpose but to be praised and worshipped by ignorant and superstitious votaries." Sampson then chronicled the apparently contradictory reasoning of the common law lawyers: "It was oral tradition as opposed to written law; it was written law, but presuming the writing lost; it was that of whose origin there was no record or memory, but of which the evidence was both in books and records." ${ }^{46}$ Sampson and his fellow codifiers thought that the time had come to discard oral tradition, and they argued instead for the sufficiency and perspicuity of legal texts (at least to qualified readers like themselves). "[] t may be safely asserted that the whole body of the Common Law has ceased to be lex non scripta, and actually is now a part of the lex scripta," Grimké wrote, and Field premised his Civil Code on the same proposition: "[A]ll that we know of the law, we know from written records. To make a Code of the known law is therefore but to make a complete, analytical, and authoritative

\footnotetext{
45 CARTER, supra note 15, at 81; Joseph HOPKInSON, CONSIDERATIONS ON THE ABOLITION OF THE COMMON LAW IN THE UNITED STATES 23 (1809). Compare with NOLL, supra note 29, at 6; Holifield, supra note 31, at 426.

${ }^{46}$ Sampson, supra note 7, at 11-12. On the logic of immemoriality in the defense of the common law, see PARKER, supra note 17 , at $30-40,152-55,182-87$.
} 
compilation from these records." Whatever oral traditions or court room practices persisted in particular locales, the written case reports were sufficient of themselves to communicate the law. ${ }^{47}$ Not only did the codifiers take a sola scriptura approach to their texts, they argued that the particular facts of the various case reports could be stripped away, leaving behind "general rules" much in the same way that Protestants defended universal propositions with "proof texts" stripped from their historical or biblical contexts. "The report of a case sets forth, at length, all the facts which it involves, the arguments of counsel, and the opinion, with all its reasons and illustrations of the Court," noted Francis Hilliard, "while the principle recognized or decided may be concisely but clearly expressed in a few marginal lines." Modern lawyers commonly extract holdings from a case, but the codifiers were venturing into uncertain territory for their time. A major puzzle they confronted was which holdings, and at what level of specificity, were fit for codification. "Some one has estimated the whole number of rules laid down in the reports at two million," Field wrote, but “[n]o man would dream of collecting and arranging all these in a code." Instead, "[t]he province of a code is not to give all the rules of law, general and particular, but only such as are general and fundamental." Where to locate the line between general or particular, fundamental or factual, would bedevil the codifiers, but they agreed the exercise was possible in principle. ${ }^{48}$

Discernment between general and needlessly particular rules was possible, the codifiers thought, because legal texts were perspicuous, a term originating in Protestant theology that American lawyers used frequently. While most codifiers did not expect legal texts to be perspicuous to all ordinary readers, they agreed with Grimké that if

\footnotetext{
${ }^{47}$ GRIMKÉ, supra note 38, at 15. David Dudley Field, Final Report of the Code Commission, in 1 SPEECHES, supra note 8, at 317,326 (1865). See also $i d$. at 322 ("Whatever is known to the judge or to the lawyer can be written, and whatever has been written in the treatises of lawyers or the opinions of judges, can be written in a systematic Code.").

${ }^{48}$ Field, supra note 47, at 319, 328. FranCIS Hilliard, THE ElEMENTS OF LAW at v (1848). David Dudley Field, Reasons for the Adoption of the Codes by New York, Address Before the Judiciary Committees of the Two Houses of the Legislature, in 1 SPEECHES, supra note 8, at 361, 367 (1873). Compare with NOLL, supra note 29, at 370-71; HATCH, supra note 22, at 81, 179-83; HOLIFIELD, supra note 31, at 494 (Protestants' "Baconian habit of assembling proof-texts.").
} 
we can lay before the inquiring reader [i.e., lawyer], not in the form of oral evidence or tradition, but in pages perfectly intelligible, the whole of the Common Law . . where can be the difficulty of determining, with the aid of talent, industry, experience and knowledge, either how much of this written Law is actually of force, or, which is far more important, and by no means so difficult, how much of it ought to be obligatory? ${ }^{49}$

In their beliefs about perspicuity, the American codifiers diverged from their English counterparts. Bentham's efforts at codification included a number of proposed institutions such as a Public Opinion Tribunal and a Legislation Minister who was responsible to maintain the "clearness" of legislation for the common people. No such institutions seemed necessary to the American codifiers. The diligent lawyer, perhaps even the lay reader, could find clear fundamental principles in the written law without these external aids, and all fundamental principles were, indeed, written. ${ }^{50}$

Against the codifiers' faith in the sufficiency and perspicuity of legal texts, the common law lawyers pleaded "the intrinsic ambiguity of language, by which we must express our intentions," as Pickering stated the position, analogizing to Protestant sectarianism. Protestants sought "to instruct us in ... a written law ..., [y]et, how many different, not to say contradictory constructions, are put upon the various parts of the sacred code, with ... confident belief, that each construction is the true one!" Protestantism vaunted perspicuity, yet "[h]ow various have been the opinions and dogmas of its professors upon what would seem to be the most plain and intelligible portions of its text." If Protestants divided in their interpretation of divine law, "[h]ow vain, then, is the hope of attaining to perfect exactness in the formation of any laws which are the work of man." ${ }^{, 1}$

\footnotetext{
49 See MiLLER, supra note 12, at 147; Stanglin, supra note 33. On the privilege of lawyerly readers, see, for instance, Nature and Method of Legal Studies, supra note 37, at 512 ("[] $\mathrm{f}$ the best code human wisdom can devise, was hung up in the office of every attorney in the land, no one of them would become great lawyers, without a thorough, scientific study of their profession.”). Grimké, supra note 38, at 16. Sedgwick linked perspicuity to popular authority when he argued that common law lawyers and codifiers were separated by their preferences for "the syllogistic mode of reasoning, [versus] the ordinary style of argument tin which a plain man would press his conclusions." [Sedgwick], supra note 38, at 417. 50 See David Lieberman, Bentham's Jurisprudence and Democratic Theory: An Alternative to Hart's Approach, in BENTHAM's THEORY OF LAW AND PUBLIC OPINION [20-22] (ed. Xiaobo Zhai, forthcoming).

51 Pickering, supra note 28, at 293-94, 297. See also HOPKINSON, supra note 45, at 25-27; note 44 supra, and text.
} 
Common law lawyers thus found similar sectarianism among the codifiers unsurprising, especially when the latter disagreed about the level of generality desirable in a code. Professed advocates of codification such as John Norton Pomeroy and William Hornblower complained about Field's Civil Code, the latter declaring it "grossly incomplete in some branches, absurdly minute in others." Favoring codification in principle, these lawyers thought Field had codified the wrong rules and drawn inappropriate distinctions between the general and the specific. Such reviews, of course, became favored citations in the New York debates. ${ }^{52}$

Even if codifiers could agree on a desired level of generality, common law lawyers argued that the indeterminacy of language made written codes inferior to the common law tradition, especially in the codifiers' ideal world of popular authority. As Pickering argued, "[T] his ambiguity of language cannot be removed by common consent in any community where each man has an equal right to decide upon the construction of the words of a language." Judgment would still be required under a code, but Carter believed that judgment in pursuit of justice would be hindered by a code that shifted disputes from principles to language: "At present ... [t] he search is for a rule ... But when the law is conceded to be written down in a statute, and the only question is what the statute means, a contention unspeakably inferior is substituted. The dispute is about words." ${ }^{53}$

A dispute about words was a tiresome exercise, unworthy of the name of judgment precisely because codifiers tried to proof-text general principles apart from the factual context of cases. An early advocate of codification in the 1820s, the New York lawyer Gulian Verplanck by 1839 had deserted to the common law lawyers, refusing to give up "the rich inheritance of decided cases, which teach the meaning of words by the example of things." It was the facts of the cases, not the holdings, which provided the law's "most perspicuous commentary." Field proposed that "that only

\footnotetext{
52 See JOHn Norton Pomeroy, The “Civil Code” IN CALIFORnia (1885) (republication by Carter's New York associates); HORNBLOWER, supra note 42, at 3.

53 Pickering, supra note 28, at 298; CARTER, supra note 15, at 85-86.
} 
is truly law which has been provided before [the facts of a particular case]," but Carter insisted that the nature of law ran in the other direction: "The fact must always come before the law. ... Apart from known, existing facts, present to the mind of the judge, or the codifier, he cannot even ask, and still less answer, the question, what is the law?" Judges discerned justice not from texts but from the experiential life of a community (through custom), and they passed on their understandings through traditions that kept both fact and holding, experience and meaning, bound together. ${ }^{54}$

By contrast, the codifiers' attempt to live without the authority of tradition sacrificed the very thing, Pickering wrote, "which gives to doubtful words a determinate signification." Only after judges considered a long series of fact-laden cases could one become reasonably sure what a text actually meant. "[S]tatutes are unsettled and liable to misconception, until a course of judicial decision, which in fact is common law, gives them certainty and character," summarized Hopkinson. From this debate, Orestes Brownson drew his conclusions that codifiers shared with Protestants a naïve view of textual authority and interpretation. ${ }^{55}$

Disagreement on whether general law could be extracted from case reports stemmed in part from the codifiers' acceptance of the Christianized common sense that Noll describes as a "scientific, universal, and optimistic" theory of knowledge. Since many common law lawyers rejected the tenets of common sense rationalism, they carried the debate into the realm of epistemology.

\section{The Means of Knowledge}

As it was in New School Protestantism, the vocabulary of common sense was abundant among the reformers of the American bar. Codifiers like Grimké confidently affirmed that "the

\footnotetext{
${ }^{54}$ GUlian C. VERPLANCK, SPEECH ON THE REFORM OF THE JUdiCIARY SYSTEM 29 (1839); DAVID DUDLEY FIELD, COdification: AN AdDress Delivered BeFore the LAW ACADEMy OF PHILAdELPHIA 22 (1886); CARTER, supra note 5, at 28. Compare with HOLIFIELD, supra note 31, at 424-25; CONTROVERSY BETWEEN THE REV. JOHN HUGHES AND THE REV. JOHN BRECKINRIDGE 20 (1833).

55 Pickering, supra note 28, at 298; HopKINSON, supra note 45, at 28. See Brownson, supra notes 1-2, and text.
} 
common sense of the people, becoming every day more enlightened" could not "suffer the indefinite continuance of the Laws, in their present condition.” Others declared that practices variously labeled Catholic, feudal, or European would appear obviously absurd if only they lost the authority of tradition. Although a few lawyers may have learned Scottish philosophy from its source, most adopted the American pairing of common sense with religious ideas of natural or biblical revelation. Hilliard's Elements of Law, for instance, reasoned that legal "rules are founded upon the basis of equity, reason, and right. If this be so, then obscurity no more belongs to the former than to the latter; upon which the instinct of conscience, the conclusions of the understanding, and the teachings of revelation, pour their mingled light.” In sum, the immediate target of American common sense rationalism was not the skepticism of David Hume, but the crippling depravity propounded by Jean Calvin. ${ }^{56}$

A major premise of American common sense (what made it "optimistic" in Noll's account) was that science properly conducted made the world simpler, and the codifiers adopted this ideal zealously. "[T] o the gaze of ignorance," wrote Grimké, "Creation is naught, but complexity and chaos; yet, to the eye of Science, the works of God are equally admirable for the simplicity of their elements, and the completeness of their system." The codifiers sought this blend of simplicity and completeness for the law, reducing the sprawling law reports to a terse, systematic set of rules. Field's favored term of common sense simplicity was plain. He hoped his procedure code would produce a "plain and rational system of procedure" that would require pleadings to give "a plain statement in ordinary language" simple enough that "a plain man" could understand them. ${ }^{57}$

\footnotetext{
56 See especially Blumenthal, supra note 22, ch. 1; Noll, supra note 29, at 93-113. GrimkÉ, supra note 38, at 21. See, e.g., [SEDGWICK], supra note 41, at 6; PARKER, supra note 17, at 68. HILLIARD, supra note 48, at vi.

${ }^{57}$ On simplicity in American common sense philosophy, see HENRY MAY, THE ENLIGHTENMENT IN AMERICA 346-58 (1976). GRIMKÉ, supra note 38, at 3. David Dudley Field, Study and Practice of the Law, in 1 SPEECHES, supra note 8, at 484, 491 (1844); David Dudley Field, What Shall be Done With the Practice of the Courts?, in 1 SPEECHES, supra, at 226, 242-44 (1847). See also FOWLER, supra note 42, at 7 ("one of the greatest problems of the time: Shall the form of the law be more simple?"). On the Protestant sense that the Bible itself was a simple book, see NoLL, supra note 29, at 382-85.
} 
Could the codifiers overcome the veneration of tradition, they believed that judgment too would become a simple task. "Nothing," wrote Sedgwick, "is . . more simple than the ownership of real property.” It was “always subject to the apprehension of the senses, and yet subtleties, quibbles, refinements, and false analogies, have been introduced into it to such an extent, that it can excite little admiration except in the eyes of a thorough bred common lawyer." If, however, procedure were freed from tradition and reformed simply to draw out relevant facts, justice would be easy to render. "[W] hen the whole facts (or truth) are known," Higgins summarized, "the decision agreeable to law is easy; the law properly being agreeable to the simplest dictates of nature and reason." Such was the premise of Field's procedure code. "Admission is the rule here," the official comment explained, "Exclusion is the rule of the common law. Let in all the light possible, we ask. Not so the common law; exclude the light, it says, lest perchance it deceive you; unmindful, as it appears to us, that poor light is better than none." Thus the new procedure codes enacted across the continent were calibrated to develop as detailed a factual record as feasibly possible. ${ }^{58}$

Common sense encouraged the codifiers that their search for general principles in the law books would yield universal legal truths. "It is impossible ... that truth is so difficult to find, as the present system supposes," Higgins wrote. True, the codifiers believed that the more facts one had, the easier judgment became, but then the facts could then be discarded and "only such [rules] as are general and fundamental would remain," according to Field. An ideal code, Fowler supposed, would be "concerned only with those larger principles indicated; those which have the force of law

\footnotetext{
${ }^{58}$ Higgins linked common sense simplicity to the issue of authority: "[S] uch laws as relate to the rights of property are so consistent with simple justice, that every man in society can understand the law, by merely deciding what would be just according to his own opinion of moral rectitude." [HIGGINS], supra note 37, at 26. [Sedgwick], supra note 38, at 424; FinAl Report of the Commissioners on Practice ANd PleAdings, in 2 Documents of the Assembly Of NeW

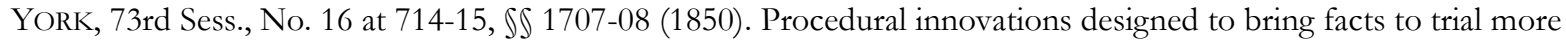
efficiently included fact pleading, modern pretrial discovery, and the qualification of parties to testify in their own causes.
} 
universally, or independently of the peculiar groups of facts to which they have, or have not, been applied." Timeless legal truth waited in the reports to be discovered. ${ }^{59}$

When discussing Carter's views, legal historians frequently point to his belief in natural, objective law as a distinguishing feature of common law "orthodoxy." Carter thought that judges only declared the law, discerning it from the facts, customs, and traditions that confronted them, and in this sense Carter believed that law had an objective existence outside the mind of the judge. ${ }^{60}$ However, the codifiers' affinity for common sense epistemology with its aims of universality and simple, timeless truth reveals that they too adhered to a type of natural law philosophy. In comparison to the common law lawyers, in fact, the codifiers embraced a notion of legal objectivity that was much more detailed than their supposed natural law opponents were willing to accept.

Catholics, of course, had pioneered the study of natural law, so one might expect them to have sympathized with the Protestant quest to codify universal law in systematic detail. However, most Catholic natural law theorists agreed with the Anglican commentator William Blackstone about the "indifference" of natural law and revelation on most civil matters. Positive law had a wide realm, and its provisions might differ widely across time and place without ever conflicting with divine law. The Protestants' mistake, Catholics argued, was that, relying only on their own reason, they too frequently elevated a provisional and culturally determined rule to the status of universal truth. The historian of theology E. Brooks Holifield notes that American Catholics in particular "delighted in displaying the ambiguities of Common Sense Realism" and argued "that the 'common sense' to which Protestants so frequently appealed was always culturally determined, taking one form in one part of the world and another in others." The common law lawyers agreed. ${ }^{61}$

\footnotetext{
59 [HIGGINS], supra note 37, at 26; Field, supra note 48, at 367; FOWLER, supra note 42, at 18.

${ }^{60}$ See HORWITZ, supra note 14, at 119; Masferrer, supra note 12, at 206.

611 BLACK. COMM. 41-42; PARKER, supra note 17, at 57-58; HOLIFIELD, supra note 31, at 421.
} 
The codifiers' mistake, Carter wrote, was the "false assumption that courts lay down rules absolutely." Devoted to a universalizing science, codifiers thought that case reports contained timeless, objective law, but the common law

takes the transactions of the past, and, by classifying them, makes its rules, but it makes them provisionally only. It declares that they are binding upon the courts only so far as respects transactions substantially like those from the examination of which the rules have been framed. In respect to future cases which may wear different aspects, it suspends judgment.

Whether a case in the present was "substantially like" one decided in the past required a skillful interpretation, not of a statutory rules, but of the facts of community life. ${ }^{62}$

The ideal of a code containing only timeless, fundamental law was an impossible dream, the common law lawyers argued, because positive law in its essence was geographically and temporally bounded: Any altered factual context could reshape a rule’s applicability and its core meaning. On this reasoning, some common law lawyers such as Carter and his New York ally Albert Mathews defined the doctrine of stare decisis quite narrowly: In their jurisprudence, it properly applied only to the judgment between the parties, not to the opinion, not even to the language of the holding. While judges were to maintain tradition, they maintained it within dynamic communities which could require modifications to the old reasoning. Thus with custom as a source of law, the common law could flexibly adapt to evolving local communities. ${ }^{63}$

Over time, common law judges recognized exceptions to general principles and forged new doctrinal paths, but codification would destroy this process and halt progress, the common law lawyers argued. In an extended analogy, Clarke compared the attempt to codify New York's law to the Christian propensity to treat the Bible as a "divine Code based on Revealed Religion" in matters of science. Too often, particular expressions in the Bible had been treated as timeless truth, but this

\footnotetext{
62 CARTER, supra note 15, at 25, 30. See also CLARKE, supra note 28, at 255.

${ }^{63}$ See CARTER, supra note 15, at 27; MATHEWs, supra note 43, at 12. On the link between custom and flexibility in Carter's jurisprudence, see Grossman, supra note 17, at 176; PARKER, supra note 17, at 241.
} 
"crystallization of ideas" thwarted human progress by preventing scientific challenges to received wisdom. The more general a rule, Carter warned, the more pernicious the effects of codification. "Suppose a general rule were enacted that promises made upon consideration were binding." Given the norm of statutory supremacy, judges were bound to render unjust verdicts unless Field codified all of the particular exceptions to the doctrine of consideration. If, on the other hand, judges freely modified the general statutory rule at their discretion, "this would have utterly destroyed [Field's] code, qua code, by converting it into a ridiculous digest," Carter scoffed; ridiculous, because it turned material fit for a treatise into a statute that people could nevertheless disregard. ${ }^{64}$

Common law lawyers thus doubted the optimistic assurances of common sense rationalists that humans could, with enough persistence, know the intricacies of natural law and write them in a simple and comprehensive order. The future held "a thousand cases that no human foresight could have comprehended in general provisions," wrote Verplanck. Only the methods of the common law, with its acceptance of provisionality and modifiability—its humility against claiming timeless truth—would effectively meet these challenges. ${ }^{65}$

By their adherence to an Americanized common sense rationalism, the codifiers proved to be more confident natural law philosophers than their common law opponents, whose views on objective law often receive more attention from scholars. They were also much more confident that they knew where history was taking them.

${ }^{64}$ CARTER, supra note 44, at 274. See also CARTER, supra note 5, at 30 ("But written law affirms that it has made an absolute classification of all possible transactions; and its rules are not subject to change or modification however illadapted they may prove to be to the business of the future to which they are to be applied."). CLARKE, supra note 28 , at 366-74.

65 VERPLANCK, supra note 54, at 29. 


\section{E. The Direction of History}

When leading codifiers looked back at the historical processes that had prepared the way for their reforms, they frequently focused not on the Enlightenment but rather on the Protestant Reformation. "The Reformation shut for ever the dark book of despotism, in religion, politics, and science," Grimké wrote, but not yet in law. Codifiers treated the common law method as a relic of Catholic England. Its rules were "the invention of the same times and same men, who" crafted the indulgence system "to make sale the mercy of God [and] the justice of man," Higgins wrote. It was only an accident of colonial history, Field thought, "that a most artificial system of procedure, conceived in the midnight of the dark ages, established in those scholastic times when chancellors were ecclesiastics and logic was taught by monks, ... was imposed upon the banks of the Hudson." 66 Codification would thus bring the liberating spirit of the Reformation to the law, and it might, some argued, help to bring about the Millennium of Christian peace and prosperity. Field's proposed international code in particular elicited this commentary. An international audience expressed skepticism at the project, but Field "with American audacity, saw no such impassible barriers," wrote his brother and biographer. "He had read the prophecy of the last days, that the valleys should be exalted and the hills made low to prepare a highway for the coming of the Prince of Peace, and every strong-armed toiler could help to clear obstructions out of the way." Field was more temperate in his own remarks before an international audience, but he nevertheless offered his code as a "law of Christendom," that if accepted "would prove a benefit to the whole human family," echoing a millennialist prophecy Protestants derived from Genesis $12 .{ }^{67}$

\footnotetext{
${ }^{66}$ GRIMKÉ, supra note 38, at 5; [HIGGINS], supra note 37, at 33; [Sedgwick], supra note 38, at 424; DAVID DUDLEY FIELD, LEGAL REFORM: AN ADDRESS TO THE GRADUATING ClAsS AT THE UNIVERSITY OF ALBANY 20 (1855); see also GEORGE HOADLY, CODIFICATION IN THE UNITED STATES 14 (1884).

${ }^{67}$ Henry Martyn Field, The Life OF DAvid DudLEy FIELD 228 (1898); David Dudley Field, Advantages of an International Code, in 1 SPEECHES, supra note 8, at 404, 415 (1869). Field argued his code was "the natural fruit of the religion which we profess," but therefore would have limited application to "Oriental nations, or, to be more precise, non-Christian nations." David Dudley Field, The Community of Nations, in 1 SpEECHES, supra at 396, 396-97 (1867); David Dudley Field, Applicability of International Law to Oriental Nations, in 1 SPEECHES, supra, at 447, 456 (1875). See also
} 
Millennial rhetoric was not just the grandiose claims of the lawyers. Codification caught the attention of lay Protestant publishers, benevolent associations, and peace societies, who linked international codification to their millennial aspirations decades before Field undertook the task. Such a "code once completed will be laid up in the hearts of the people, as in a holy ark of the covenant," wrote the Christian Examiner in 1841, alluding to a millennial prophecy from Jeremiah. ${ }^{68}$

For codifiers and New School Protestants, codes possessed millennial implications because of their power to unite people under the same laws and institutions. Unlike the numerous and evergrowing volumes of case reports, a code could be copied from one jurisdiction and easily enacted in another-as had happened numerous times for Field's procedure code by the 1870 s. As more jurisdictions adopted the same statutes, conflicts of law would disappear, and legal institutions could establish higher levels of federation, culminating in a congress of nations that could secure world peace. Before Field attempted to codify international law, he had hoped his domestic codes would fill the role, providing

a CODE AMERICAN, not insular but continental, as simple as so vast a work can be made, free in its spirit, catholic in its principles! and that work will go with our ships, our travelers and our armies; it will march with the language, it will move with every emigration, and make itself a home in the farthest portion of our own continent, in the vast Australian lands, and in the islands of the southern and western seas.

The promise of codification thus lay in the hope that universal legal principles could in fact become universal positive law. ${ }^{69}$

\footnotetext{
HOADLY, supra note 66, at 30-31 ("Then, but not till then, do I believe the effervescing energies of legislation . . will head the mandate, "Peace be still."). Compare especially with HATCH, supra note 22, at 184-89.

${ }^{68}$ Essays on a Congress of Nations, 29 CHristian EXAMINER 83, 88 (1841). See also CHARLES Loring BRACE, GESTA CHristi: A History OF HuMANE PROGRESS UNDER CHRISTIANITY 357 (1888). Jerimiah 31:31-34. ${ }^{69}$ On the spread of the procedure code, see CHARLES M. HEPBurn, THE HistORICAL DeVELOPMENT OF CODE PlEADING IN AMERICA AND ENGLAND (1897). FIELD, supra note 66, at 32; see also HOADLY, supra note 66, at 30 ("What I hope and claim is, that before many years a code of rights as well as remedies, the same in substance, though very likely differing in detail, will be in force in every American State, and within the limits of its powers, be adopted by federal legislation.").
} 
Codifiers posed cataclysmic events — the Protestant Reformation, the inauguration of the Millennium — and plotted law reform efforts between them, but common law lawyers held to a different historical sensibility that lacked a cataclysmic vocabulary and emphasized continuity over time. Kunal Parker's work explores the prominent idea of the "insensibility" of common law change. Law in the common law system changed over time, but it changed so gradually and in such step with broader society as to be nearly imperceptible. As Parker argues, American common law lawyers admired the thought of Edmund Burke, who defended the insensible development of English law against the enchantment of cataclysmic revolution. Even when a historian could trace the genealogy of a rule to a particular enactment, the process by which the rule passed into broader legal tradition was ultimately "mysterious," Burke contended, thus embracing a concept of authority and tradition the American codifiers abhorred..$^{70}$

Common law lawyers did not necessarily disagree that history was moving towards greater legal unity, but they resisted the idea that codification could achieve that end. Instead, only the common law method produced the advantageous "tendency of the private law of all English speaking States to a unity," Carter proclaimed. Carter's supporting argument that "[r]ight, reason, and justice are ... everywhere the same" seems to belie his belief that common law rules were provisional and determined by local culture. Carter supposed, however, that Americans were becoming more culturally united, and only as this convergence progressed would the "reciprocal influence of intellectual and legal culture ... bring all private law into unison.” Private law remained culturally determined, but as American culture became more uniform, so too-insensibly—would the law. Codes, on the other hand, cemented disunity into writing, Carter argued, unless states enacted

\footnotetext{
70 PARKER, supra note 17, at 40-41, 80-84; on Carter and insensibility, see especially $i d$. at 242 . On the codifiers' attitude toward mystery, see note 40 supra and text. On the Catholic response to American Protestant millennialism, see HowE, supra note 22 , at 319-23.
} 
exactly the same words with exactly the same interpretation-but the codifiers could not achieve that feat without granting significant authority to an interpretive hierarchy. ${ }^{71}$

In their historical sensibilities, the common law lawyers shared an affinity with Catholicism for the continuity of tradition that changed only imperceptibly and mysteriously. In their efforts at legal unity, they believed the common law promised catholicism in a non-theological sense: It was an all-embracing method that could adapt within an increasingly unified America.

\section{F. Religious Identity of the Codifiers \& Common Law Lawyers}

On matters of authority, the interpretation of written texts, the means of knowledge, and the direction of history, the leading theorists of codification shared the worldview and assumptions of New School Protestantism as it had developed in America. To a significant degree, they shared the New School Protestants' theological commitments as well, or else they maintained close family connections, partnerships, or cultural ties with those who did. Many outspoken code proponents such as David Dudley Field, Henry Sedgwick, Francis Wharton, Jesse Higgins, Thomas Smith Grimké or the western codifier W. A. Scott were devout Protestants, often leading members of New School Presbyterian churches. Others like William Sampson, George Hoadly, and Joseph Rantoul were less vocal about their faith in their adult lives, but as sons, brothers, or partners of prominent ministers and evangelical philanthropists, they shared the concerns of the more intellectual strands of New School Protestantism. As the sections above demonstrate, the codifiers often moved explicitly beyond mere analogy and joined their jurisprudence with their religious thought.

The leading common law defenders were much more religiously diverse than the codifiers, although they tended to share an antipathy towards revivalist Protestantism. Some, like Gulian

\footnotetext{
${ }^{71}$ CARTER, supra note 5, at 51-52. Even in the same sentence, Carter affirmed both universal objectivity and cultural determinism: "Right, reason, and justice are however everywhere the same, and in proportion as the popular standards of different States are cultivated they are brought more and more into unison." Id. On linguistic ambiguity and cultural determinism, see notes 51, 62-63 supra and text.
} 
Verplanck, John Pickering, and William Hornblower, adhered to Old School or high church Protestant denominations that denigrated revivalism and rejected its philosophy of authority and interpretation. A significant number, including James Carter, Francis Lieber, and R. Floyd Clarke were religious modernists or outspokenly irreligious. Almost none were Catholic, although Carter's law partner Charles O'Conor was one notable exception. ${ }^{72}$ The common law lawyers occasionally analogized to the follies of Protestant sectarianism and biblical literalism, but usually their arguments showed little more than an affinity for Catholic of Old School Protestant thought.

In light of America's de facto Protestant legal establishment at the time, this difference between the codifiers and common law lawyers' explicit appeal to religious thought makes sense. Where their theological commitments seemed to support their jurisprudence, Protestant codifiers readily drew the connections and offered them as compelling arguments. Authority, perspicuity, epistemology, and millennialism could be joined in a coherent worldview for both law and religion. Their opponents had no similar motivation (committed Catholic apologists like Orestes Brownson excepted). If Carter and his associates ever realized that their attack on American codification and its Protestant underpinnings echoed Catholic theology, they had nothing to gain in saying so. Rather, like the Gilded Age elites studied by Jackson Lears, common law lawyers embraced Catholic forms - either for functional or aesthetic reasons — while studiously rejecting Catholic dogma. ${ }^{73}$ None of this means that one's religious views necessarily determined a stance on codification in nineteenth-century America. A New School Protestant might well have concluded that the doctrines of perspicuity and popular authority properly applied only to the Bible within Christian churches (indeed, this appears to have been the view of Hornblower, a Presbyterian defender of the common law). Codification in Canada progressed as a Roman Catholic undertaking, since codes

\footnotetext{
${ }^{72}$ Carter's devoutly Catholic law partner during the prosecution of the Tweed ring, O'Conor was rumored to have influenced Carter's jurisprudential development. See Current Topics, 31 ALB. L.J. 161 (1885).

73 T. J. Jackson Lears, No Place of Grace: Antimodernism and the Transformation of American Culture 183-98 (1981).
} 
seemed to be the best security for Catholic political and religious rights, while the German opponent of codification Carl Friedrich von Savigny considered his jurisprudence an extension of his deeply Protestant commitments. ${ }^{74}$ The point is rather than when many American codifiers argued about authority, interpretation, knowledge, and history, they frequently drew upon their familiar Protestant intellectual culture. This affinity gave the American codification debates a different character than in England or Europe. On the other side of the Atlantic, the leading proponents of positivism and codification—Comte, Mill, Bentham, Austin, Cambacérès, Thibaut—-tended to be religious radicals, dismissive of traditional Catholic and Protestant Christianity alike. In America, religiously indifferent or heterodox lawyers were more often the defenders of a conventional legal method. In their opposition to the Protestant impulses underlying American codification, they emphasized tradition, hierarchy, mystery, and continuity, and aligned their arguments — ironically at times — with those of American Catholics, high church Episcopalians, or Old School Presbyterians.

\section{Conclusion}

American proponents of codification cast their proposals in the language and logic of the revivalist Protestantism that rose to prominence in the nineteenth century. They rejected the authority both of tradition and of judicial hierarchies and elevated instead the authority of ordinary people. They believed in the sufficiency of written legal texts to communicate the law, and they argued that such texts were perspicuous to ordinary readers like themselves. In their adherence to a Christianized common sense epistemology, they optimistically hoped to extract universal, timeless truths from factually laden case reports, and could they succeed in this endeavor, some of them believed that statutory law could unite the world for the coming Christian millennium.

\footnotetext{
74 See generally HORnBlower, supra note 42. See BriAn J. YOUnG, THE POLITICS OF CODIFICATION: THE LOWER CANADIAN Civil CODE OF 1866 at 117-20 (1994); JAMES Q. WHITMAN, THE LEGACY OF THE ROMAN LAW IN THE GERMAN ROMANTIC ERA: HistoricAl Vision AND LEGAL CHANGE 3-40 (1990).
} 
In attacking these positions, common law defenders struck at the assumptions of American Protestantism, often mirroring the arguments propounded by American Catholics or Old School Protestants. They insisted legal authority had to be mediated to common people, and that the ambiguities of written texts made the judicial hierarchy with its interpretive traditions the best mediators. Suspicious of common sense rationalism, they believed that common law rules were provisional, culturally determined, and only imperceptibly changeable in the flow of tradition.

American lawyers thus adhered to two different but fundamentally coherent worldviews that shared very few assumptions about authority, interpretation, knowledge, or history. That the debates became so fierce and attracted so much attention from lawyers and laymen alike is therefore unsurprising: The codification controversy was a conflict of paradigms in the fullest sense. ${ }^{75}$

Paying attention to the theological structure of the debates helps us to understand why this chapter in American legal history seems to have closed with the nineteenth century. The intensity of the codification controversy came to an abrupt end as the structure of thought known as "modernism" came simultaneously to American theology and American law (the liberal biblical scholar Charles Augustus Briggs, for instance, was acquitted of heresy just before Oliver Wendell Holmes Jr. penned "The Path of the Law"). Creating and elevating the role of the expert social scientist, modernism offered a paradigm that rejected both popular authority and tradition, common sense and romantic mystery. Part of the codification project endured, but with a new philosophy undergirding it. The dismantling of the Protestant establishment further meant that in the twentieth

\footnotetext{
75 Thomas S. Kuhn, The Structure OF SCIEnTIFic Revolutions (3d. ed., 1996 [1962]). Kuhn's model is particularly helpful in thinking through the American codification debates. Kuhn argues that because paradigms are fundamentally incommensurate, proponents of contending paradigms necessarily talk past each other and tend to win the "debate" not by the strength of their arguments but by their ability to recruit the rising generation of professionals. Masferrer is disturbed by the appearance that Carter and Field "were simply talking past each other," but instead of exploring their positions as coherent paradigms, he reduces the debate to personal jealousy. Masferrer, supra note 12, at 190.
} 
century, the Catholic defense against Legal Realism came, in fact, from respected Roman Catholic jurists. ${ }^{76}$

The continuation of statutory consolidation in the era of legal modernism has obscured the significant discontinuity of thought between the nineteenth century codifiers and the modern theorists of legislation. The basis for the codifiers' positivism, their optimistic views on perspicuity, and their millennial zeal pose significant challenges for those who wish to see the codifiers as rational champions of statutory law, living ahead of their time. The trial structures they bequeathed were premised on the simplicity of knowledge and calibrated to make factual investigation as easy as possible, a regime that many contemporary lawyers, including a majority on the U.S. Supreme Court, now find problematic. ${ }^{77}$

Scholars, however, have devoted most of their attention to the common law defenders, assuming their "premodern" viewpoint so late in the nineteenth century is the major puzzle requiring explanation. Though some have written entire books on the theories of American common law lawyers while saying little or nothing about the proponents of codification, such an approach is unsound. Many of the common law lawyers wrote self-consciously apologetic works that they felt had been provoked by the codifiers. We must therefore pay attention to how these movements developed in response to one another. Doing so reveals that on occasion it was the common law lawyers who could seem ahead of their time. The problem of language and the uncommonness of common sense were not phenomena suddenly discovered in the 1970s, after all. Common law lawyers made these concepts the heart of their critique, in some ways anticipating and

\footnotetext{
76 See Mark S. Massa, Mediating Modernism: Charles Briggs, Catholic Modernism, and an Ecumenical "Plot,” 81 HARV. Theological ReV. 413 (1988); Oliver Wendell Holmes, The Path of the Law, 10 Harv. L. REV. 457 (1897); David J. Seipp, Holmes's Path, 77 BOSTON U. L. ReV. 515 (1997); PARKER, supra note 17, at 4-11; EdwARD PuRCELL, THE CRISIS of Democratic Theory: SCIENTIFIC NAturalism AND THE Problem OF VAlue 159-80 (1973).

77 See Bell Atlantic Corp. v. Twombly, 550 U.S. 544 (2007); John H. Langbein, The Disappearance of the Civil Trial in the United States, 122 YALE L.J. 522 (2012).
} 
seeking to avoid the problems of statutory interpretation that have arisen in recondite battles over the number and sequence of steps in Cherron analysis, for instance. ${ }^{78}$ Perhaps the common law lawyers, then, are not so strange as they have seemed, nor are the codifiers so familiar. Such after all is the task of history-and of theology. ${ }^{79}$

78 See, e.g., Kenneth A. Bamberger \& Peter L. Strauss, Chevron's Two Steps, 95 VA. L. REv. 611 (2009); Matthew C. Stephenson \& Adrian Vermeule, Chevron Has Only One Step, 95 VA. L. ReV. 598 (2009).

79 Walter Benjamin, The Arcades Project 471 N7a,7 \& N8,1 (Suhrkamp Verlag, trans.; Rolf Tiedmann, ed., 1999). 